\title{
PROMOTION OF GEOTOURISM AND GEOHERITAGE AT THE OASES OF OUED NOUN
}

\author{
Saïd MIRARI* \\ Mohammed V University, Faculty of Science in Rabat, Laboratory of Tourism Engineering, Heritage \\ and Sustainable Development of the Territories, P.O. BOX 1014 RP, Rabat, Morocco, e-mail: Mirarisaid@gmail.com \\ Abdelouahed BENMLIH \\ Mohammed V University, Faculty of Science in Rabat, Laboratory of Tourism Engineering, Heritage \\ and Sustainable Development of the Territories, P.O. BOX 1014 RP, Rabat, Morocco, e-mail: benmlihabdelouahed@yahoo.fr
}

Citation: Mirari, S., \& Benmlih, A. (2020). PROMOTION OF GEOTOURISM AND GEOHERITAGE AT THE OASES OF OUED NOUN.

GeoJournal of Tourism and Geosites, 32(4), 1433-1440. https://doi.org/10.30892/gtg.32435-591

\begin{abstract}
The objective of this study is to restore the value of Oued Noun Oases that has been less estimated for several centuries, without destroying the collective memory. Our duty is to look through certain models of geotourism and geoheritage practiced elsewhere, which would be the best approach to preserve this natural landscape that has become very fragile. A systematic survey was conducted on several selected geosites, including inventory, characterization, classification, evaluation and appreciation. That is to say, qualitative and quantitative assessme nts were carried out on the basis of geoheritage values of international significance. This paper is focused on the efforts should be made in all these sites to ameliorate and develop geoheritage and geotourism in Oued Noun Oases. This research is conducted not only for scient ific research and indication of sites, but also to developing geological, ecological and cultural infrastructu res within the reach of tourists.
\end{abstract}

Key words: Geotourism, Geosite, Geoheritage, Geodiversity, Development and Oued Noun Oases

$* * * * * * *$

\section{INTRODUCTION}

Sustainability is a principle of action; however, investigating closely this concept, reveals that it does not cover a unified program. A group of factors could be considered as solutions to the current problem only if there is a growing governance in the recognition of the gravity of the issue. According to an advanced regionalization plan, Morocco has adopted a new policy of development that integrates the environmental component, the rationalization of natural resources, measures for poverty reduction and an appropriate social a nd spatial distribution of wealth (Benkada et al., 2018). Geotourism, which is a new and fundamental concept in the vision of tourism traced by the government for 2020, has currently been demonstrated as a key factor for sustainable development.

The field of tourism responds to a strong demand when it takes into account the programs and the strategic plans implemented by the decision makers and the players of the industrial tourism (Reynard et al., 2017; Pica et al., 2017). Oued Noun Oases faces numerous natural, human-induced, institutional, organizational and legal constraints. Hence, there is a need for a practical tool that would reconcile the imperatives of conservation (Hakim and Soemarno, 2017), the demands of the local population and tourism, and at the same time positively address the constraints that hamper the management of the site. It, therefore, constitutes a sector of undeniable tourist value and an important tourist destination according to its specialization in the territorial offer and thanks to the particularity and specificities of its goods and services related to the geotourism activity that could arise (Nazaruddin, 2019). The identification of geological heritage values (Lazzarini et al., 2014; Brilha, 2016) constitutes the first principle in the elaboration of geotourism circuits and the basis for promoting the revitalisation of rural areas through new tourism opportunities (Ólafsdóttir, 2019; Farsani et al., 2011). This orientation is reflected in the initiation of a broad debate within society on the subject of geotourism, geoheritage and geoconservation (Carcavill et al., 2008, Carcavilla et al.,2009, Poiraud et al., 2017, Duval et al., 2010), in a world of increased industrialization, the environmental issues have been omitted (Henriques et al., 2011). The need to preserve the ecological and geological (El Hadi et al., 2015) space is a major concern in an economic context that promotes the integration of alternative tourism in the new philosophy of the national strategy in the tourism sector (Mirari and Benmlih, 2018).

\section{STUDY AREA}

The Oases of Oued Noun are situated in Guelmim-Oued Noun region, province of Guelmim, on a surface of 2170 ha (Chmourk, 2011). The province establishes a buffer zone between Sahara and Souss on a surface of $10783 \mathrm{Km}^{2}$ that is $18.34 \%$ of the total surface of the region. It is limited by the province of Sidi-ifni in the north, the province of Tan-Tan in the WS, the province of Assa-Zag in the East, the Atlantic Ocean West and the province of Tata (Souss-Massa region) in the East (HCP, 2015).

The plain of Guelmim is a part of the western anti-atlas. It contains two main morphological units: the trays of limestone of western antiatlas and Jbel Baní which is considered the source of Feijas (Weisrock et al., 2006), establishing a bridge between the desert zone and the semiarid sub. The city possesses a dry and Saharan climate (MEMWE, 2010) due to the interference of several geologic and geomorphologic aspects: the closeness of the Atlantic Ocean, the influence of the cold currents, and the presence of a mountainous barrier of the anti-atlas (SMDHBA, 2013). All these factors insure a protection against the east and south east sandy winds in addition to the effect of the Saharan continental character, especially in summer. The average annual temperature is $19,6{ }^{\circ} \mathrm{C}$ (SMDHBA, 2013).

The hydrological network of surface is established by three main wadis: Noun, Bouissafe and Aouriouira, on a $9300 \mathrm{Km}^{2}$ surface. The aquifer represents the underground water resources: the deep aquifer at oscillating levels of lower limestone of the Georgian then the groundwater and alluvial aquifer between 15 and $45 \mathrm{~m}$ (Mahmouhi et al., 2016). The biodiversity of the various ecosystems of the region is based on a sheltered biotope. Thanks to their aridity and the rarity of human activity and especially in a little isolated area, numerous endemic species find an environment which is favorable to them (Cuzin, 2003). The region contains a vegetable belt of forests on 31700 ha,

\footnotetext{
${ }^{*}$ Corresponding author
} 
as well as an identified and endemic flora, according to the peculiarities of each life area. The fauna consists of a fair important number of mammalian organisms, avian, amphibians and rare and endangered reptiles (Bergier et al., 2017).

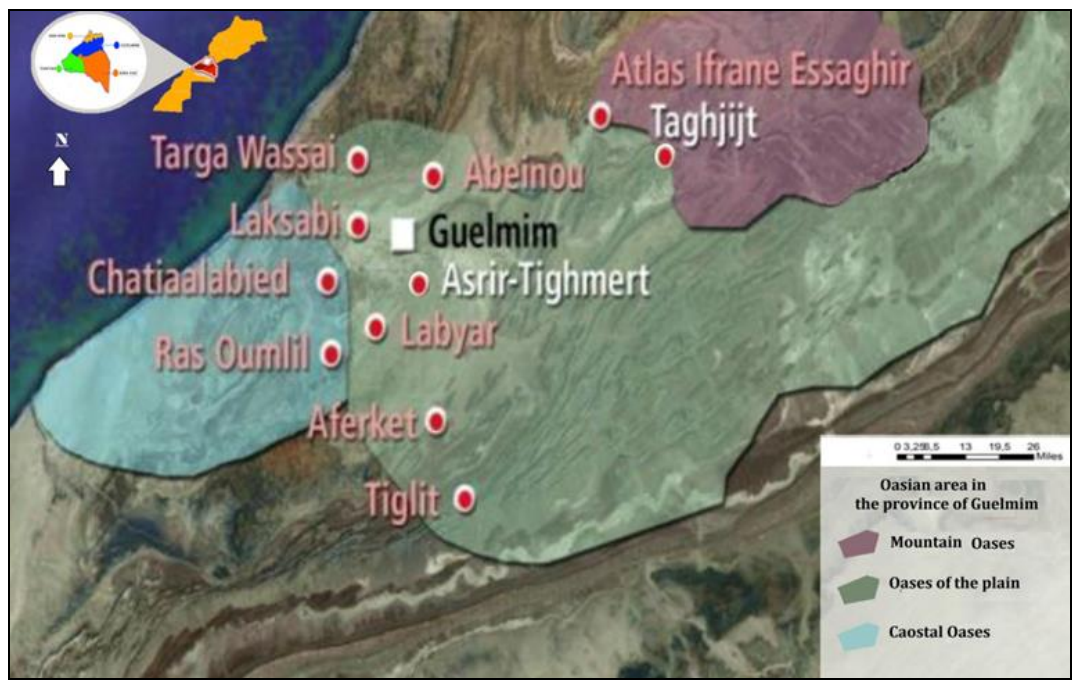

Figure 1. Oasian area in the Oued Noun Oases

\section{Geographical and Geological outline of the study area}

The chosen study region is located on the southwest of Guelmim city (N28 9 , W10 02 , altitude $540 \mathrm{~m}$ ), in a large synclinorium which forms, on a regional scale, a narrow depressed basin between the Precambrian basement in the South and the Paleozoic cover in the North (Belfoul et al., 2001; Michard et al., 2011).

The lithostratigraphic successions of the region (Table 1) studied are basically formed by Cambrian formations, formed by shales with paradoxids and by sandstones with conocoryphs and lingules (SMDHBA, 2013). The Ordovician series are represented by green silstones of lower arenig age, the thicknesses is $150 \mathrm{~m}$ contain trilobites, Graptoliths as well as Echinoderms (Destombes et al., 1985). On the geological map (Figure 2) of Goulimine and the lower Drâa wadi, these basic terrains pass towards the summit with sandstones and quartzites dating from the middle arenig. Their thickness does not exceed $50 \mathrm{~m}$ (Naser, 2006). Caradoc-age quartz deposits and micro-conglomeric sandstones form the last visible bars before the tectonic contact of E-W direction which separates them from detrital carboniferous deposits (Figure 2). These facies are similar to the periglacial Ashgill age (Ettayfi, 2013; Pique et al., 2007). Between the pleated Bani and the Devonian ridges of the Rich, lies the plain of Assa-Aouinat Torkoz, whose quaternary (Pique et al., 2007) cover generally masks the Silurian shales.

Beyond the Western anti-atlas, also pleated, but with more moderate relief than the Bani, spreads out again a broad plain, that of the Drâa wadi with shale (Choubert, 1963) substratum of the Upper Devonian, most often masked by the quaternary alluviums. On another note a geological point of view, the Guelmim area is part of the Anti-Atlantic chain elongated in a WSW-ENE direction, where Precambrian and Sub-Cambrian to Cambrian terrain outcrops (Pique et al., 2007). The southern slope of the Anti-Atlas, to which the region belongs, has a fairly gentle slope with sharp ridges (HCWFFAD, 2008). The terrain is of post-Cambrian Paleozoic age (Pique et al., 2007).

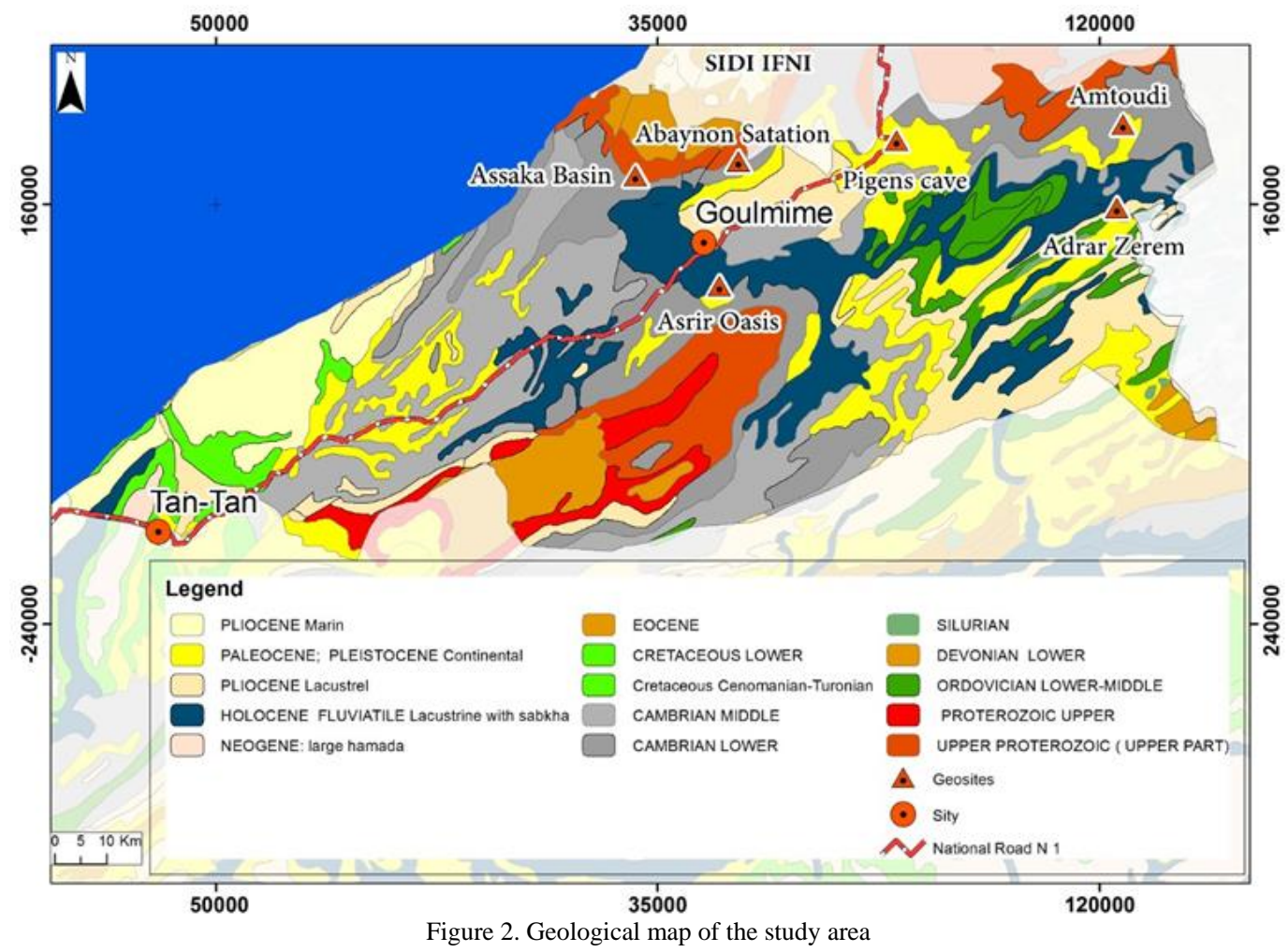


Table 1. Synthetic stratigraphic column of the Plioquaternary of the Guelmim plain SMDHBA, 2011

\begin{tabular}{|c|c|l|}
\hline \multirow{4}{*}{ Plioquaternaire } & Unit & \multicolumn{1}{c|}{ Stratigraphic units } \\
\cline { 2 - 3 } & \multirow{4}{*}{ Unit 4 } & $\begin{array}{l}\text { - Scree regs and cones at the foot of the reliefs } \\
\text { - Limestone crust, saline crust } \\
\text { - Alluvium, sand and pebbles around watercourses, silt on the plain. }\end{array}$ \\
\cline { 2 - 3 } & \multirow{2}{*}{ Unit 3 } & $\begin{array}{l}\text { - Alternation of : } \\
\text { - Lake limestones } \\
\text { - Sandy marls passing laterally to sandy clays } \\
\text { - Marly to marnocalcareous limestone with sand passages }\end{array}$ \\
\cline { 2 - 3 } & Unit 2 & $\begin{array}{l}\text { - Presence of fossil bed alluvium below these formations } \\
\text { - Conglomerate }\end{array}$ \\
\hline Acadian & Unit 1 & Surface weathered shale with inclusion of sandstone levels \\
\hline
\end{tabular}

\section{MATERIAL AND METHODS}

This article is based on a set of materials which contain literatures, maps, and photographs related to Oued Noun Oases. The methodology used in this work is the inventory of geosites, its characteristics, classification and evaluation. The inventory was carried out by the identification, classification and distribution of the most important geosites of the Oases through a geological survey. The survey was developed by reading literature reviews, field trips and interviews with specialists in local geological heritage.

The geosites characterization was based on direct observation, relevant selection, detailed description and specialized classification through work on geodiversity (Gray, 2005), vision between the works of Pralong, 2006; Brocx and Semeniuk, 2007; Predrag and Mirela, 2010 and the scale (Brocx and Semeniuk, 2007) (Nazaruddin, 2019).

Two evaluation approaches are adopted for the development of this article: a qualitative approach (Aoulad-Ali et al., 2019; Nazaruddin, 2019), which gives particular attention to the geographic and geological heritage values for classification and description, a quantitative approach which aims to assess the geosites and its geoheritage value and SWOT analysis to establish development strategies.

\section{RESULTS}

\section{Inventory of gosites}

The enhancement and the conservation of the geological heritage (Chakrabarty and Mandal, 2020) have become very important in several countries (Giusti, 2012), especially for sites that have scientific, cultural or economic interest (Ranjbaran et al., 2020). This importance is mainly due to the appearance of a strong tourist demand, who no longer seeks " $4 \mathrm{~S}$ " tourism (Sand, Sea, Sex, Sun) (Cheng, 2016) but "4E" tourism from the beginning of this millenniumto improve awareness of responsibility: Educational tourism, Environment and clean nature, culture and history Event, Entertainment and fun.

The Guelmim plain encompasses a vast territory that greatly exceeds the sole area of the Oases; it is to incorporate pre-desert areas of great scenic beauty, but also to house elements that constitute the geological wealth of the plain (Mirari and Benmlih, 2018). To select geosites of geoheritage significance, several criteria must be taken into account: Uniqueness, representativeness and rarity (Predrag and Mirela, 2010; Brocx al., 2011; Pralong, 2006). In this map (Figure 2), we offer some geosites of geotourism importance with a descriptive table.

Table 2. List of selected geosites as potential geoheritage resources and geotourism attractions in Oued Noun Oases

\begin{tabular}{|c|c|c|c|c|}
\hline $\mathbf{N}^{\circ}$ & Geosite & Location & Main geological feature & Other Characterizations \\
\hline 1 & Amtoudi & $\begin{array}{l}\text { Rural Municipality Amtoudi: } \\
\text { N } 29^{\circ} 14.930^{\prime} ; \text { W9 }{ }^{\circ} 11.127\end{array}$ & $\begin{array}{l}\text { Illustration of the Lower Cambrian formations } \\
\text { corresponding to the upper limestones, the } \\
\text { schisto-limestone series, the schistous series and } \\
\text { the terminal sandstones. }\end{array}$ & $\begin{array}{l}\text { the sandstone-quartzitic series of the } 1 \text { st Bani and the } \\
\text { plain corresponding to Feijas which are covered with } \\
\text { quaternary deposits }\end{array}$ \\
\hline 2 & $\begin{array}{c}\text { Adrar } \\
\text { ZerZem }\end{array}$ & $\begin{array}{l}\text { Rural municipality Taghjijt: } \\
\text { N } 28^{\circ} 926 ; \text { W } 9^{\circ} 042\end{array}$ & $\begin{array}{l}\text { It is in the form of a rocky ridge oriented E.- } 0 . \\
\text { which overlooks the right bank of the Seyad wadi }\end{array}$ & $\begin{array}{l}\text { The engraving station is located on the rocky outcrops } \\
\text { overlooking the plain alluviale surrounding }\end{array}$ \\
\hline 3 & $\begin{array}{c}\text { Abaynou } \\
\text { station }\end{array}$ & $\begin{array}{l}\text { Rural municipality d'Abaynou } \\
\mathrm{N}^{\circ} 29^{\circ} 093 ; \mathrm{W} 10^{\circ} 019 \\
\end{array}$ & $\begin{array}{l}\text { It is an emergence of this Saudi tablecloth appear } \\
\text { at the northern limit of the Guelmim basin }\end{array}$ & Sandy clay generally less than 7 meters thick \\
\hline 4 & $\begin{array}{c}\text { Pigeon } \\
\text { cave }\end{array}$ & \begin{tabular}{|l|} 
Rural municipality Ait Boufoulen \\
N $29^{\circ} 300 ;$ W9 ${ }^{\circ} 695$
\end{tabular} & $\begin{array}{l}\text { The caves are made up of a set of dark and } \\
\text { narrow rocks }\end{array}$ & $\begin{array}{l}\text { Rainwater enters and emerges in a pond called Bizane } \\
\text { in Agjgal wadi. }\end{array}$ \\
\hline 5 & $\begin{array}{c}\text { Assaka } \\
\text { Basin }\end{array}$ & \begin{tabular}{|l|} 
Rural municipality Targa Wassay \\
N $29^{\circ} 07 ;$; $W 10^{\circ} 25^{\prime}$
\end{tabular} & \begin{tabular}{|l} 
Georgian and Precambrian mass forms an \\
external feija broad of 5Kms on average
\end{tabular} & $\begin{array}{l}\text { It is made up of eruptive rocks dating from the } \\
\text { Precambrian II and III (Andesites, Basalts and Granites). } \\
\end{array}$ \\
\hline 6 & $\begin{array}{l}\text { Asrir } \\
\text { Oasis }\end{array}$ & $\begin{array}{l}\text { Rural municipality of Asrir } \\
\text { N } 29^{\circ} 074 ; \text { W } 9^{\circ} 432\end{array}$ & $\begin{array}{l}\text { It is made up of schist, sandstone and Georgian } \\
\text { limestones, belonging to the upper part of lower } \\
\text { limestone of the Adoudounian }\end{array}$ & - \\
\hline
\end{tabular}

The characterization of the geosites was developed by direct observation and description of the sites during the field trips and supported by data from the literature and interviews with geology scientists and the locals. These geosites have a noticeable geological importance which must enhance its geoheritage, such as geological, archaeological, morphological, hydrogeological and sociocultural values. The following part is a description of the selected geosites at Oued Noun Oases, Guelmim province.

\section{Geosite "Amtoudi"}

This site is a Berber village in southern Morocco (Figure 3) it has a very rich landscape of the Western Anti-Atlas. It is an oasis of mountainous nature located at the bottom of a canyon where about 325 households live.

With a respectable age of more than 2 billion years, the Stromatoliths of the Anti-Atlas correspond to discoid or nippled constructions produced by mats of bacteria, mainly cyanobacteria (blue algae). Islands are formed elongated fossils forming a relief, about 1 to $5 \mathrm{~cm}$ high. They can be caused by the agitation of the swell on the beaches, or the action of sea currents on the bottom. They are found on the upper surface of a finely detrital layer and bear witness to a shallow marine environment.

\section{Amtoudi travertines}

On an altitude of $930 \mathrm{~m}$ with geographic coordinates $\mathrm{N} 29^{\circ} 14.361^{\prime}$; W9 $10.108^{\prime}$ (Figure 4), there are travertines which show a particular type of limestone rock which forms at the emergence of certain sources and on the slopes of river beds, as a result of changes in the physicochemical conditions induced by plants and algae which fix carbon dioxide causing precipitation of travertine. 


\section{Amtoudi waterfall and Bougaa source}

At an altitude of $931 \mathrm{~m}$, with geographic coordinates N29⒕36'; W9 ${ }^{\circ} 10.108^{\prime}$, a log of Oued Amtoudi follows the old faults where water flows all year round (Figure 5); the springs and waterfalls are the result of a resurgence in the gorges cut into the shale-limestone alternation of the lower Cambrian at the bottom of the palm grove of Amtoudi. The First village includes a great part of Agadir (RoblesMarín et al., 2014), spread over the two rivers, but at fairly high level and perched on the cliffs, some were inaccessible. The history of the word Agadir which is the emblem of the region is often explained as collective granaries, and Agadir designates the nose of an eagle.

\section{Amtoudi's stratigraphy}

Illustration of the Lower Cambrian formations which corresponds to the upper limestones, the schistolimestone series, the schistous series and the terminal sandstones (Figure 6). The "upper limestones" are a transgressive set of dolomites and limestones ranging in thickness from around $400 \mathrm{~m}$ in the Western Anti-Atlas to $75 \mathrm{~m}$ or even $0 \mathrm{~m}$ in the eastern part of the massif.

\section{Archaeological Geosite "Adrar Zerzem"}

The Adrar ZerZem Site is located in the rural commune of Taghjijt, 80km towards Tata (Figure 7). This site dates back to almost 2,500 years before our era (Louart et al., 2013). A quality of about 37 mortuary monuments of former Amazigh inhabitants and other monuments confirm human settlement in the region (BOKBOT et al., 2005). This area shelters a very important archaeological complex which includes several types of vestiges: rock engravings showing a great thematic variety, burial mounds connected to other dry stone structures with circular plan, and finally, an outdoor habitat with abundant archaeological material surface.

These discoveries will contribute to the enrichment of historical research concerning this important period in the history of Morocco which preceded the discovery of the Moroccan coasts by Phoenician sailors (Figure 8).

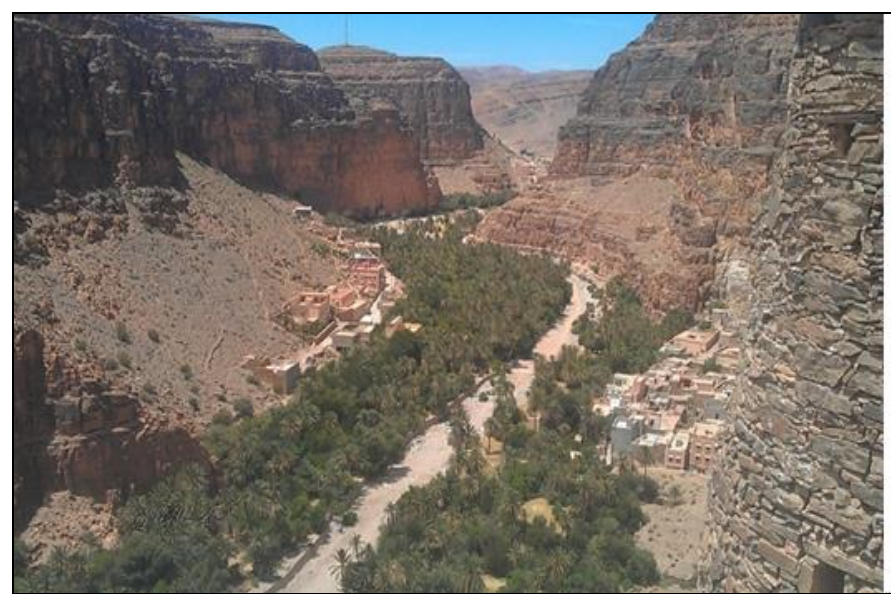

Figure 3. Panoramic view of the Amtoudi basin

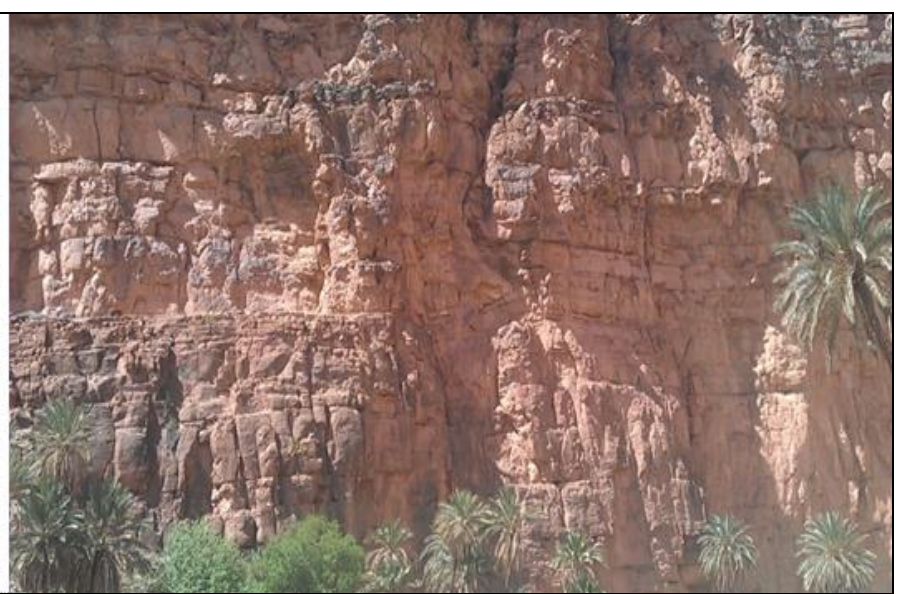

Figure 4. The Amtoudi lineaments

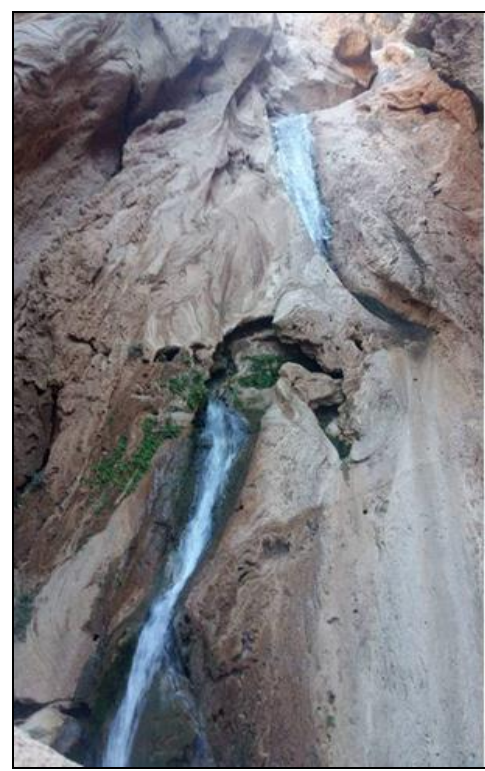

Figure 5. Bougaa source

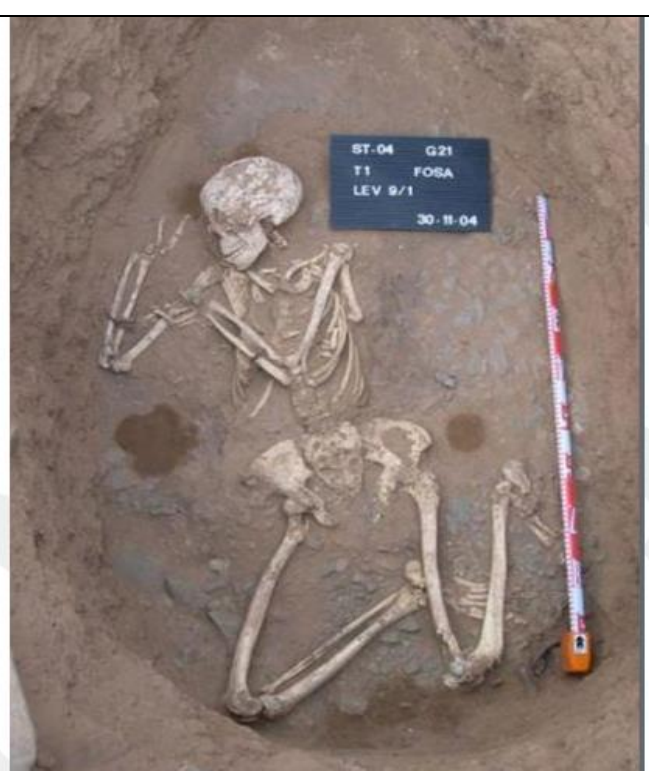

Figure 6. Tumulus in "Adrar Zerzem ((Bokbot et al., 2005)

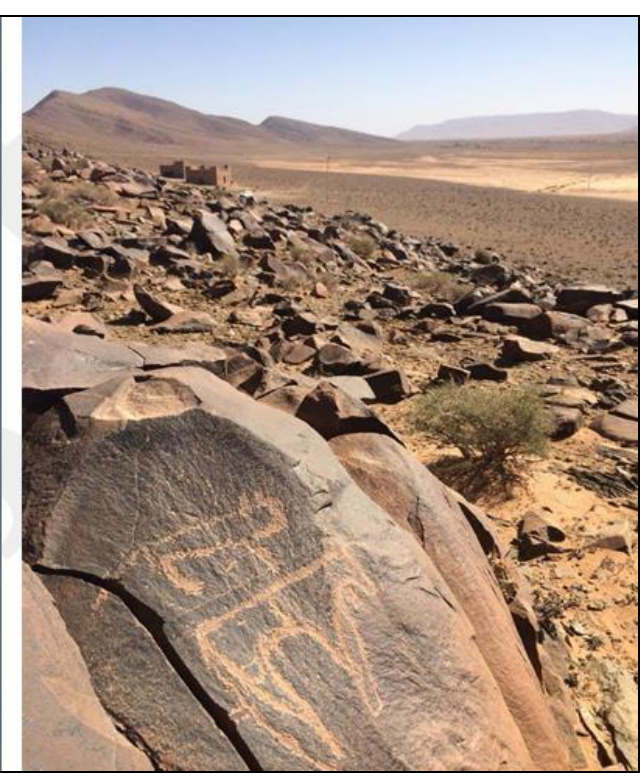

Figure 7. Rock carvings

\section{Geomrphological geosite "Cave of pigeons"}

Located at Ait Boufoulen $50 \mathrm{~km}$ towards Agadir (Figure 9), the caves are made up of a set of dark and narrow rocks. Access to these caves is difficult. A set of palm groves is spread across the geographic space of this site, among others, such as those of Bouzakarn and Ait Boufoulen.

\section{Thermal Geosite "Abaynou"}

The Abaynou source, located at the rural commune of Abaynou $10 \mathrm{~km}$ to the north, is an outlet of this Adoudounian water table appearing at the northern limit of the Guelmim basin (Figure 10). Water of this spring comes out with a temperature of $45^{\circ} \mathrm{C}$ and a sulphatecalcium facies. Its origin is deep and probably appears at a fault affecting the Georgian limestones of the West of Ouggoug Oases 
(SMDHBA, 2013). In the upper part, at the entrance to the gorge taken by the Guelmim-Ifni road, there are thick banks of black limestone. The series are said to be 400 to $500 \mathrm{~m}$ thick south of Abaynou. This unit is distinguished by more accentuated reliefs, with a characteristic light color on satellite images. The water from this spring has healing properties, particularly with regard to dermal and rheumatic diseases.

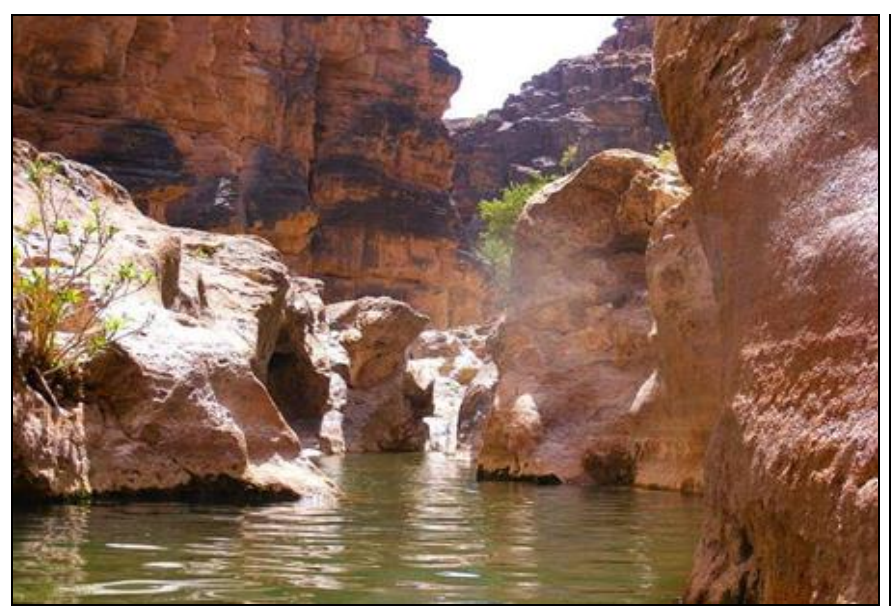

Figure 8. The waterfalls of the wadi Amtoudi

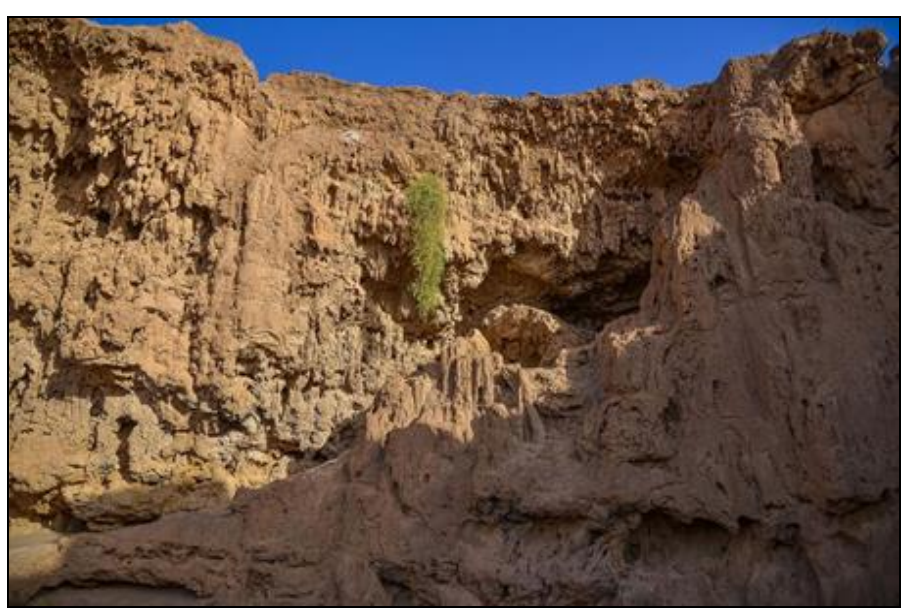

Figure 9. Travertine in the vicinity of the cave

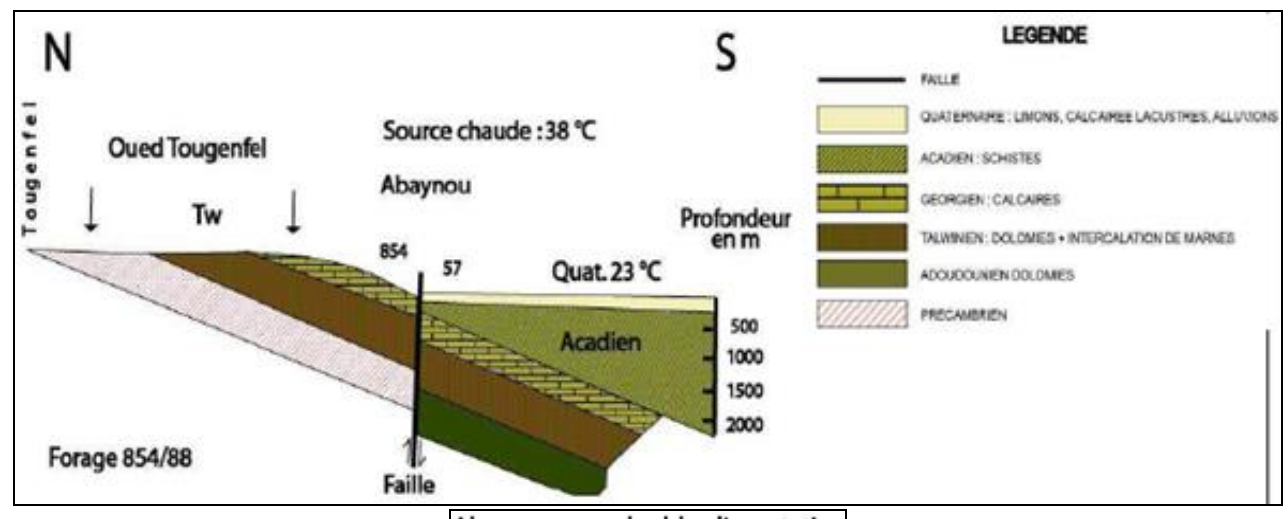

Abaynou: une double alimentation

Figue 10. Chematic section illustrating the deep origin of the source of Abayno, SMDHBA.2013

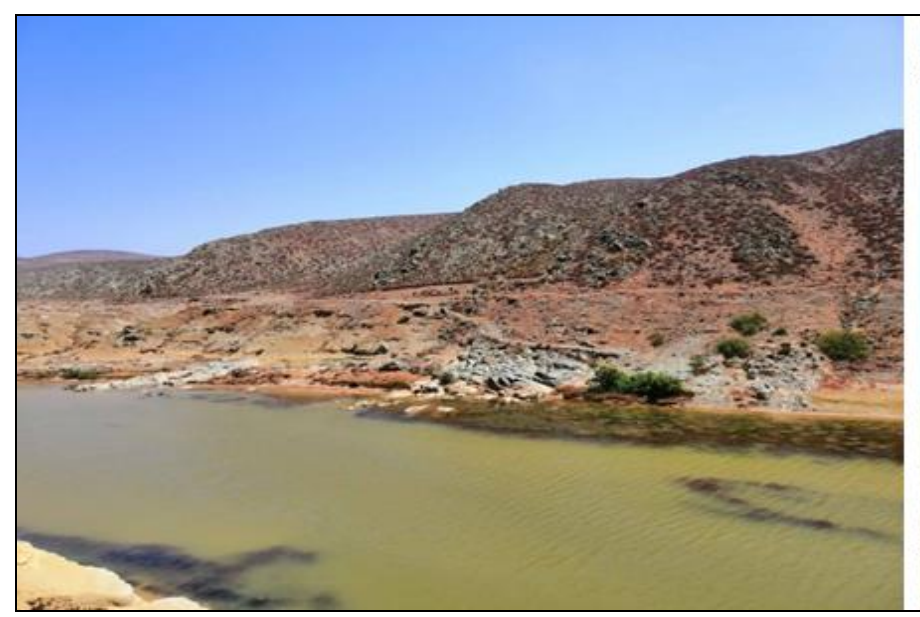

Figure 11. A panoramic view of the Assaka bassin

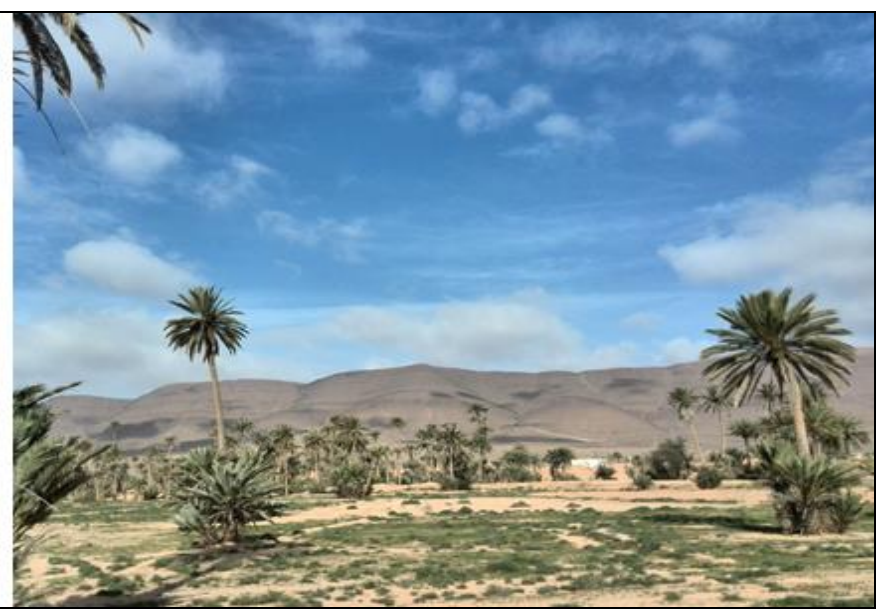

Figure 12. A panoramic view of the Asrir oases

\section{Hydrogeological geosite "Assaka Basin"}

A beautiful outcrop of sandstone and greenish subhorizontal shales on the Seyad wadi (dip of 5-10 ${ }^{\circ}$ to the SE). We are at the top of the "terminal sandstones", in the zone of passage to the schists at paradoxides (Figure 11). The terminal sandstones were formerly stored in the lower Cambrian, but are now dated to the beginning of the middle Cambrian. The top of several benches shows bioturbations and asymmetrical ripple marks in the N-S direction. The Wadi bed is guided by these deaclases (Weisrock et al., 2006).

\section{Sociocultural geosite "Asrir Oases"}

The Asrir Oases, formerly known as "Noul-Lamta" (Joumani, 2008), has played a very significant role in the history of the southern provinces (Figure 12) thanks to its strategic position between the Atlas Mountains and the Atlantic plains. Asrir represented a place of ancient settlement of human groups and a point of convergence and crossing point for many transhumant tribes. Furthermore, this site shows particular, cultural, archaeological and geotourist features which are represented by rock shelters, Kasbahs, granaries and others. 


\section{Classification of geosites}

Table 3. The classification of selected geosites

\begin{tabular}{|c|c|l|l|c|}
\hline $\mathrm{N}^{\circ}$ & Geosites & \multicolumn{1}{|c|}{ Geodiversity } & \multicolumn{1}{|c|}{ Scope } \\
\hline 1 & Amtoudi & Relief / Landscape / Rock & Geomorphological & \multicolumn{1}{|c|}{ Big ladder } \\
\hline 2 & Adrar ZerZem & Relief / Landscape / & Archaeological & Medium scale \\
\hline 3 & Abaynou station & Relief / Rock and Hydrological Process & Geomorphological / hydrogeological & Medium scale \\
\hline 4 & Pigeon cave & Relief / Landscape / Rock & Geomorphological & Medium scale \\
\hline 5 & Assaka Basin & Hydrological process & Hydrogeological & Geomorphological \\
\hline 6 & Asrir Oases & Relief / Landscape / Oasis & Big ladder & \\
\hline
\end{tabular}

Table 4. Qualitative assessment of selected geosites for potential geoheritage resources and geotourism attractions in Oued Noun Oasis, Morocco

\begin{tabular}{|c|c|c|c|c|c|c|}
\hline $\mathbf{N}^{\circ}$ & $\mathbf{1}$ & 2 & 3 & 4 & 5 & 6 \\
\hline geosites & Amtoudi & Adrar Zerzem & Abaynou station & Pigeon cave & Assaka Basin & Oasis Asrir \\
\hline $\begin{array}{c}\begin{array}{c}\text { Scientific } \\
\text { (and } \\
\text { educational) } \\
\text { value }\end{array} \\
\text { alue }\end{array}$ & $\begin{array}{c}\text { Formation of the cascade } \\
\text { and diaclase scade and } \\
\text { diaclase lithology }\end{array}$ & $\begin{array}{c}\text { Formation of the rock } \\
\text { engraving process, } \\
\text { Tumulus }\end{array}$ & $\begin{array}{l}\text { Hot spring process training } \\
\text { / Geothermal system }\end{array}$ & $\begin{array}{c}\text { Cave / } \\
\text { sinkhole } \\
\text { formation }\end{array}$ & $\begin{array}{c}\text { Formation processes } \\
\text { of waterfall; the } \\
\text { lithology of the } \\
\text { waterfall }\end{array}$ & $\begin{array}{c}\text { Formation of the } \\
\text { Oasis / Fieja } \\
\text { process }\end{array}$ \\
\hline $\begin{array}{l}\text { Aesthetic } \\
\text { value }\end{array}$ & $\begin{array}{c}\text { Relief and Landscape and } \\
\text { panoramic view of the } \\
\text { Anti-Atlas }\end{array}$ & $\begin{array}{l}\text { Relief and Landscape of } \\
\text { Monuments }\end{array}$ & $\begin{array}{c}\text { Relief and Landscape / } \\
\text { Biodiversity }\end{array}$ & $\begin{array}{l}\text { Relief and } \\
\text { Landscape of } \\
\text { Discovery }\end{array}$ & $\begin{array}{l}\text { Vegetable landscape } \\
\text { of middle mountains }\end{array}$ & $\begin{array}{l}\text { Pre-Saharan } \\
\text { landscape }\end{array}$ \\
\hline $\begin{array}{c}\text { Recreational } \\
\text { value }\end{array}$ & $\begin{array}{l}\text { Leisure activities and } \\
\text { hiking on site }\end{array}$ & $\begin{array}{c}\text { Discovery activities and } \\
\text { scientific research }\end{array}$ & $\begin{array}{l}\text { Leisure activities, hiking } \\
\text { and swimming }\end{array}$ & $\begin{array}{c}\text { Exploration } \\
\text { activities }\end{array}$ & $\begin{array}{c}\text { Leisure activities, } \\
\text { hiking }\end{array}$ & $\begin{array}{c}\text { Leisure activities, } \\
\text { hiking }\end{array}$ \\
\hline $\begin{array}{l}\text { Cultural (and } \\
\text { historical) } \\
\text { value }\end{array}$ & $\begin{array}{c}\text { An Amazigh village in } \\
\text { southern Morocco / } \\
\text { heritage of the collective } \\
\text { granary }\end{array}$ & $\begin{array}{l}\text { the history of Morocco } \\
\text { which preceded the } \\
\text { discovery of the } \\
\text { Moroccan coasts by } \\
\text { Phoenician sailors. }\end{array}$ & - & - & - & $\begin{array}{l}\text { Dating of the site } \\
\text { exists during the } \\
\text { Almoravids } \\
\text { period (Noul- } \\
\text { Lamta) } \\
\end{array}$ \\
\hline $\begin{array}{l}\text { Aesthetic } \\
\text { value }\end{array}$ & $\begin{array}{c}\text { Relief and Landscape and } \\
\text { panoramic view of the } \\
\text { Anti-Atlas }\end{array}$ & $\begin{array}{l}\text { Relief and Landscape of } \\
\text { Monuments }\end{array}$ & $\begin{array}{c}\text { Relief and Landscape / } \\
\text { biodiversity }\end{array}$ & $\begin{array}{c}\text { Relief and } \\
\text { Landscape of } \\
\text { Discovery }\end{array}$ & $\begin{array}{l}\text { Vegetable landscape } \\
\text { of middle mountains }\end{array}$ & $\begin{array}{l}\text { Pre-Saharan } \\
\text { landscape }\end{array}$ \\
\hline $\begin{array}{l}\text { Functional } \\
\text { value }\end{array}$ & - & - & $\begin{array}{l}\text { Curative virtues in particular } \\
\text { with regard to dermal and } \\
\text { rheumatic diseases }\end{array}$ & - & - & - \\
\hline Religious value & National & International & Regional & State & State & National \\
\hline Contents & documentary & Iconographic & Symbolic & Indicial & Indicial & Indicial \\
\hline
\end{tabular}

Table 5. Numerical assessment of selected geosites for potential geoheritage resources and geotourism attractions in Guelmim Oasis

\begin{tabular}{|c|c|c|c|c|c|c|c|c|c|}
\hline $\mathrm{N}^{\circ}$ & $\begin{array}{c}\text { Geological } \\
\text { site }\end{array}$ & $\begin{array}{c}\text { Scientific (and } \\
\text { educational) value }\end{array}$ & $\begin{array}{c}\text { Aesthetic } \\
\text { value }\end{array}$ & $\begin{array}{c}\text { Recreational } \\
\text { value }\end{array}$ & $\begin{array}{c}\text { Cultural (and } \\
\text { historical) value }\end{array}$ & $\begin{array}{c}\begin{array}{c}\text { Economic } \\
\text { value }\end{array} \\
\end{array}$ & $\begin{array}{c}\text { functional } \\
\text { value }\end{array}$ & $\begin{array}{c}\text { Significance } \\
\text { level }\end{array}$ & Total \\
\hline 1 & Amtoudi & 5 & 5 & 5 & 5 & 5 & 0 & 4 & 29 \\
\hline 2 & Adrar ZerZem & 5 & 5 & 2 & 5 & 0 & 0 & 5 & 22 \\
\hline 3 & Abaynou station & 5 & 5 & 5 & 0 & 5 & 5 & 3 & 28 \\
\hline 4 & Pigeon cave & 5 & 5 & 0 & 0 & 0 & 0 & 2 & 28 \\
\hline 5 & Assaka Basin & 5 & 5 & 3 & 0 & 2 & 0 & 3 & 18 \\
\hline 6 & Asrir Oases & 5 & 5 & 5 & 5 & 5 & 0 & 4 & 29 \\
\hline
\end{tabular}

\section{DISCUSSION}

The degradation processes with the action of mass tourism presents a strong threat to the oases of Oued Noun. However, care must be taken to avoid any disturbance that could, in the long term, affect its biological and heritage quality through geotourism. The Amtoudi site and Asrir oasis represent the main heritage of Oued Noun Oases and they must be maintained in an optimal ecological state as much as possible.

This synthesis values the quality of the Oases's geosite and geodiversity, the sharing of geoconservation standards, best practices in geotourism development, the exchange of expertise and support for geoheritage preservation (Henriques et al., 2011; Reynard and Brilha 2018; Gordon et al., 2018). On the other hand, this synthesis makes it possible to present the geosites with a notion of responsibility and at the same time to valorize the quality of the geodiversity of the selected ones. The selected geosites of the Guelmim Province have been classified according to the following classification: geodiversity, scope and scale. According to Gray (2005), geodiversity is divided into eight components: rock, mineral, fossil, relief, landscape, processes, soil and other georesources. Predrag and Mirela (2010) and Brocx and Semeniuk (2007) have classified geosites as petrological, stratigraphic, mineralogical, (palentological), geomorphological, speleological, hydrological/hydrogeological, structural, etc., sites. Brocx and Semeniuk (2007) classified geosites into six categories based on scale: regional/megascale (coverage of $100 \times$ $100 \mathrm{~km}$ or more), large/macro-scale (coverage of $10 \times 10 \mathrm{~km}$ or more), medium/mesoscale (coverage of $1 \times 1 \mathrm{~km}$ or more), small-/microscale (coverage of 10-100 m $\times 10-100 \mathrm{~m}$ or more), fine/leptoscale (coverage of $1 \times 1 \mathrm{~m}$ or more), and very fine-scale (coverage of $1 \times 1 \mathrm{~mm}$ or more).

Two approaches have been carried out to scientifically evaluate the geosites of the Guelmim Province, qualitative and quantitative:

The qualitative approach is based on the values of geological heritage (Gray, 2004, 2005). Especially scientific values (related to geological meanings and interests); educational values (related to earth sciences and environmental education); aesthetic values (related to landscape beauty features); recreational values (related to recreational and tourist activities); cultural values (related to cultural and historical values); economic values (related to financial characteristics); functional values (related to use characteristics), etc

On the other hand, the quantitative approach was developed to evaluate sites in a numerical way or to rank them according to their geopatrimonial values. For natural heritage values, six values were established for this study: $0=$ none, $1=$ very poor, $2=$ poor, $3=$ fair, $4=$ good and $5=$ very good. In contrast, for levels of significance, there are five categories of values: $1=$ local, $2=$ regional, $3=$ national, $4=$ international and 5 = international. In effect, Brocx and Semeniuk (2007) presented the levels of significance (ranking) according to the level of importance of these sites, which must also be determined, including international, national, state, regional and local levels.

In addition, Pena dos Reis and Henriques (2009) presented the contents displayed by geological objects are designated as indexical (a clear relationship between geological processes and their products), iconographic (a particular geological phenomenon), symbolic (an image with 
geological characteristics used by the public) at the local scale.For documentary (a phenomenon understanding geological changes), scenic (a phenomenon with a great recreational function) at the regional scale.Finally, the conceptual (a reference to singular geological occurrences) on a global scale. The geoswites of the province of Guelmim are composed by reliefs, landscapes, rocks, waters and oases. Besides, these geosites are possessed by relief features (geomorphological sites), such as oasis, waterfall, mountain and cave. A hot spring phenomenon that is classified as a hydrogeological site is also a valuable resource of the province. An archaeological area contains a very important landscape that includes several types of remains. A hydrological area has a very rich biodiversity (Table 1). These sites range from small to large scale (Table 2 ). These qualitative and quantitative assessments can speak directly to the priority that should be given to geosites for geoconservation and development efforts. On the other hand, three geosites are designated for the geological objective Indicial and the three other geological objectives are developed: documentary, symbolic and iconographic (Table 3). Geosites with higher scores or values should receive greater attention and priority. Table 4 presents the scores obtained for each site with regard to geoheritage values and levels of significance. The SWOT analysis was used to assess the strengths, weaknesses, opportunities and threats of geosites in the province of Guelmim and to help decide on geoconservation and geotourism development efforts (Mirari et al,. 2020) The SWOT analysis of all these sites can be found in Table 5.

Table 6. SWOT presents a diagnostic analysis of the selected geosites

\begin{tabular}{|c|c|c|c|c|c|}
\hline $\mathbf{N}^{\circ}$ & Geosites & Strength & Weakness & Opportunity & Threat \\
\hline 1 & Amtoudi & $\begin{array}{l}\text { Quality environment: a landscape } \\
\text { heritage, an archaeological heritage } \\
\text { and a cultural and historical heritage }\end{array}$ & $\begin{array}{l}\text { The Establishment of reception } \\
\text { facilities on the ground such as } \\
\text { rest areas }\end{array}$ & $\begin{array}{c}\text { Fragility of the most precious } \\
\text { and most visited ecosystems; } \\
\text { Low environmental } \\
\text { awareness and education }\end{array}$ & $\begin{array}{l}\text { Failure to comply with } \\
\text { environmental management prin ci } \\
\text { Growing tourist pressure }\end{array}$ \\
\hline 2 & $\begin{array}{l}\text { Adrar } \\
\text { ZerZem }\end{array}$ & $\begin{array}{l}\text { Quality environment: a landscape } \\
\text { heritage, an archaeological heritage } \\
\text { and a cultural and historical heritage }\end{array}$ & $\begin{array}{l}\text { Establishment of reception } \\
\text { facilities on the ground such as } \\
\text { rest areas; The layout of the trackss }\end{array}$ & $\begin{array}{l}\text { Inaccessibility } \\
\text { Lack of signage }\end{array}$ & $\begin{array}{l}\text { Destruction of environments } \\
\text { Possibility of losing cultural identity }\end{array}$ \\
\hline 3 & $\begin{array}{c}\text { Abaynou } \\
\text { station }\end{array}$ & Typical surrounding villages & $\begin{array}{c}\text { The development of } \\
\text { the slopes }\end{array}$ & $\begin{array}{c}\text { Low Environmental } \\
\text { awareness and education }\end{array}$ & $\begin{array}{r}\text { Growi } \\
\text { pr }\end{array}$ \\
\hline 4 & $\begin{array}{c}\text { Pigeon } \\
\text { cave }\end{array}$ & Typical surrounding villages & $\begin{array}{c}\text { Environmental } \\
\text { education }\end{array}$ & $\begin{array}{c}\text { Inaccessibility } \\
\text { Lack of signage }\end{array}$ & $\begin{array}{r}\text { Destruction of environn } \\
\text { Possibility of losing cultural } \\
\end{array}$ \\
\hline 5 & $\begin{array}{l}\text { Assaka } \\
\text { Basin }\end{array}$ & $\begin{array}{l}\text { The Destination with high } \\
\text { biodiversity: magnificent landscapes } \\
\text { - fauna and flora diversity - } \\
\text { preserved and diversified ecosystem }\end{array}$ & $\begin{array}{l}\text { Environmental } \\
\text { education }\end{array}$ & $\begin{array}{l}\text { Fragility of the most precious } \\
\text { and most visited ecosystems }\end{array}$ & $\begin{array}{c}\text { Failure to comply with } \\
\text { Environmental management } \\
\text { principal }\end{array}$ \\
\hline 6 & $\begin{array}{l}\text { Asrir } \\
\text { Oases }\end{array}$ & $\begin{array}{l}\text { Quality environment: a landscape } \\
\text { heritage, an archaeological heritage } \\
\text { and a cultural and historical heritage }\end{array}$ & $\begin{array}{l}\text { The establishment of reception } \\
\text { facilities on the ground such as rest } \\
\text { areas; The development of tracks }\end{array}$ & $\begin{array}{c}\text { Fragility of the most precious } \\
\text { and mosvisited ecosystems; Risk } \\
\text { of silting up and desertification }\end{array}$ & $\begin{array}{c}\text { Failure to comply with environmental } \\
\text { management Princi ples Growing } \\
\text { tourist pressure }\end{array}$ \\
\hline
\end{tabular}

The promotion of geosites in the region understudy and its networking to constitute geotourism routes like certain themed circuits can constitute a factor of development and enhancement of this region of southern Morocco. These circuits have been designed to discover the geological and archaeological history of the region through all of the geosites, where it is possible to find information and infrastructures intended to the public. This policy may represent a new offer for encouraging the promotion of cultural tourism.

Geosites provide essential scientific information. They represent the beauty of the landscape, and allow reconstructing the history and the geological processes of the region. These archives of nature, very numerous and diverse in southern Morocco, will undoubtedly generate significant tourist flows if they are well valued.

\section{CONCLUSION}

The geographical location of the Oued Noun Oases gives this territory a great potential for sustainable development with an interesting geological experience that has not yet been exploited. Certain rules and tools are required systemically and responsibly to a development policy within the framework of an Oued Noun Oases development project and the creation of a geoterritorial image.

The observation scale begins at the local platform to take into account the problems, the different issues and the impacts on geosites. Development must, however, integrate a reflection on a global scale to consider external elements such as climatic factors, the structure of geosites and the policy adopted at the regional level. In this respect, the oases's diversity of exceptional landscapes predisposes it to play an important role in geotourism, which must respect the environments and the biodiversity. In this sense, care must be taken to promote respectful geotourism and geoheritage in the Oued Noun Oases in general and in the Amtoudi geosite and Asrir Oases in particular.

The target is to protect and preserve the local, cultural and natural geoheritage. It will be the same for the rationalization of socioeconomic activities and the involvement of all in a responsible and sustainable spirit.

\section{Acknowledgement}

This strategy will constitute a real initiative for sustainable development and according to the charter that will be established, it will become possible to observe rules of respect for the environment, the geological and cultural heritage of the region.

\section{REFERENCES}

Aoulad-Sidi-Mhend, A., Maaté, A., Amri, I., Hlila, R., Chakiri, S., Maaté, S., \& Martín, M.M. (2019).The Geological Heritage of the Talassemtane National Park and the Ghomara coast Natural Area (NW of Morocco). Geoheritage.11, 1005-1025. https://doi.org/10.1007/s12371-019-00347-4

Beggier, P., Thevenot, M., Qninba, A., \& Houllie, J.R. (2017). Evolution of the avifauna of a contact zone between Saharan and non-Saharan Morocco in 60 years. Go-South Bull, 14, 142-161.

Belfoul, M.A., Faik, F., \& Hassenforder, A.B. (2001). Evidence of a tangential tectonic event prior to the major folding in the Variscan belt of western antiAtlas. Journal of African Earth Sciences, 32 https://doi.org/10.1016/S0899-5362(02)00051-9

Benkada, A., Beloucgi, M., Lallouchen, A., \& Essarsar, M. (2018). Regional financial governance: a lever for change for advanced regionalization in Morocco. International Journal of Scientificand Engineering Research. 9, 8.

Bokbot,Y. Rodriguez A., Onrrubi-Pintado, J., Rodriguez-Santana, G., Velasco-Vazquez, J., \& Amarira, A. (2005). The funeral and cult complex of Adrar Zerzem (Anti-Atlas, Morocco), Preliminary results. African Iniquities Studies, 21-29.

Brilha, J. (2016). Inventory and Quantitative Assessment of Geosites and Geodiversity Sites: a review. Geoheritage, 8, 119-134. http://dx.doi.org/ 10.1007/s12371-014-0139-3

Brocx, M., \& Semeniuk, V. (2007). Geoheritage and Geoconservation - History, Definition, Scope, and Scale. Journal of the Royal Society of Western Australia, 90, 53-80.

Carcavilla, L., Durán, J.J., Garcia-Cortés, A. \& López, M.J. (2009). Geological heritage and geoconservation in Spain: Past, present and future. Geoheritage, 1, 75-91. http://dx.doi.org/10.1007/ s12371-009-0006-9 
Carcavilla, L., Durán, J.J., \& López M.J. (2008). Geodiversity: concept and relationship with geological heritage. Geo-Temas, VII Geological Congress of Spain. Las Palmas de Gran Canaria, 10, 1299-1303

Chakrabarty, P., \& Mandal, R. (2019). Geotourism Development for Fossil Conservation: A Study in Amkhoi Fossil Park of West Bengal in India. GeoJournal of Tourism and Geosites, 27(4), 1418-1428. https://doi.org/10.30892/gtg.27425-444

Cheng, F.L. (2016). An investigation of factors determining industrial tourism attractiveness. Tourism and Hospitality Research, 16(2), 184-197. http://dx.doi.org/10.2307/26366483

Chmourk, E. (2011). The Oued Noun Oases: degradation of the natural environment and prospects for development. Journal Cinq Continents, 1(2), 105-117.

Choubert, G. (1963). Geological history of the Precambrian Anti-Atlas. Notes and Memoirs of the Geological Service of Morocco. 1, 85-123

Cuzin, F. (2003). Large mammals of southern Morocco (High Atlas, Anti-Atlas and Sahara), Distribution, ecology and conservation. Doctoral thesis in science. University of Montpellier II. France.

Destombes, J., Hollard, H., \& Willefert, S. (1985). Lower Paleozoic rocks of Morocco. in Lower Palaeozoic of North-Western and West-Central Africa, edited by C.H. Holland, Trinity Coll., Dep. of Geol., Dublin, Ireland, 4, $91-336$.

Duval, M., \& Gauchon, C. (2010). Tourism, geosciences and territorial issues: news on geotourism. Téoros, 29 (2), 3-14. https://doi.org/10.7202/1024865ar

El Hadi, H., Tahiri, A., Brilha, J., El Maidani, A., Baghdad, B., \& Zaidi, A. (2015). Geodiversity Examples of Morocco: From Inventory to Regional Geotourism Development. Open Journal of Ecology, 5, 409-419. http://dx.doi.org/10.4236/oje.2015.59034

Ettayfi, N. (2013). Chemical and isotopic characterization of groundwater in the Western Anti-Atlas (Lakhssas-Tafraout) to assess recharge, water-rock interaction, salinity and residence time. Ph.D. thesis in science, University of Ibn Zohr Agadir.Morocco.

Farsani, N.T., Coelho, C., \& Costa, C. (2011). Geotourism and geoparks as novel strategies for socio-economic development in rural areas. International Journal of Tourism Research, 13(1), 68-81. https://doi.org/10.1002/jtr.800

Giusti, C. (2012). with a geomorphological interest - an invisible heritage? Géocarrefour, 87/3-4. https://doi.org/10.4000/geocarrefour.8834

Gordon, J.E., Roger, C., \& Enrique, D.M. (2018). Geoheritage Conservation and Environmental Policies. Chapter in Geoheritage, 213-236. http://dx.doi.org/10.1016/B978-0-12-809531-7.00012-5

Gray M. (2004). Geodiversity: Valuing and Conserving Abiotic Nature. John Wiley, Chichester, 434. https://doi.org/10.4000/geomorphologie.416

Gray M. (2005). Geodiversity and Geoconservation: What, Why, and How? The George Wright Parks Stewardship Forum, 22(3), 4-12.

Hakim, L \& Soemarno, M. (2017). Biodiversity Conservation, Community Development and Geotourism Development in Bromo-Tengger-Semeru-Arjuno Biosphere Reserve, East Java. GeoJournal of Tourism and Geosites, 20(2), 220-230.

Henriques, M.H., Pena dos Reis, R., Brilha, J., \& Mota, T.S. (2011). Geoconservation as an emerging geoscience. Geoheritage, 3, 117-128. http://dx.doi.org/10.1007/s12371-011-0039-8

Joumani, A. (2008). The Asrir oasis: elements of the social history of Oued Noun. Collection History and societies of southern Morocco. P.40

Lazzarini, M., \& Aloia, A. (2014). Geoparks, Geoheritage and Geotourism: Opportunities and Tools in Sustainable Development of the Territory. GeoJournal of Tourism and Geosites. 13, 8-9.

Louart, A. Alaoui, A., Bokbot,Y., Onrubia, J.P., Sanchez, C.A., \& Fleitas, A.R. (2013). Rock art landscapes and settlements in the Noun wadi basin (PreSaharan Morocco). The upper valley of the Seyyad wadi. Actes la septième rencontre Quaternalistes Marocains RQM7, Agadir, 66-78.

Mahmouhi, N., El Wartiti, M., Astite, W.S., Kemmou, S., \& El Bahi, S. (2016). The use of geographic information system for the extraction of physical characteristics of assaka watershed: sub-basins of sayed and oum laachar wadis (southern Morocco) International Journal of Innovation and Applied Studies, 16(2), 370-377

Michard, A., Rjimati, E., \& Saddiqi., O. (2011). Western Anti-Atlas and Saharan Provinces, Notes and Memoir, 561(6), edition of the Geological Survey of Morocco, Rabat.

Mirari, S., \& Benmlih. A. (2018). The Sustainable Development of Oued Noun Oases through the Integration in the Biosphere Reserve Oasis of Southern Morocco. International Journal of Science and Research (IJSR). 7(11), 1211-1218. http://dx.doi.org/10.21275/ART20192816

Mirari, S., Aoulad-Sidi-Mhend, A., \& Benmlih, A. (2020). Geosites for Geotourism, Geoheritage, and Geoconservation of the Khnefiss National Park, Southern Morocco. Sustainability, 12, 7109. https://doi.org/10.3390/su12177109

Naser, N. (2006). Use of geographic information systems in hydrology for the development of a water resources management tool for the Guelmim basin. Thesis of State Engineer in Rural Engineering, Institute of Agronomy and Veterinary Medicine Hassan II, Rabat. p 24.

Nazaruddin, D.A. (2019). Selected geosites for geoheritage, geotourism, and geoconservation in Songkhla Province, South 7 ern Thailand. Quaestiones Geographicae, Bogucki Wydawnictwo Naukowe, Poznań, 38(1), 161-177. http://dx.doi.org/ 10.2478/quageo- 2019-0011

Ólafsdóttir, R. (2019). Geotourism. Geosciences, MDPI, 9, 48. http://dx.doi.org/10.3390/geosciences 9010048

Pena dos Reis, R., \& Henriques, M.H. (2009). Approaching an Integrated Qualification and Evaluation System for Geological Heritage. Geoheritage, 1(1), 110. http://dx.doi.org/10.1007/s12371-009-0002-0

Pica, A., Luberti, G.M., Vergari, F., Fredi, P., \& Del Monte, M. (2017). Contribution for an urban geomorphoheritage assessment method: proposal from three geomorphosites in Rome (Italy). Quaestiones Geographicae, Bogucki Wydawnictwo Naukowe, Poznań, 36(3), 21-36. http://dx.doi.org/10.1515/quageo-2017-0030

Pique, A., Soulaimani, A., Amhrhar, M., La Ville, E., Bouabdelli, M., Hoepffner, C., \& Chalouan, A. (2007). Geology of Morocco. Editions GEODE, Marrakech, 9-19.

Poiraud, P., \& Dandurand, G. (2017). From geoconservation to geotourism: a paradigm shift. Annales de Géographie, 717, 625-653.

Pralong, J.P. (2006). Geotourism and the use of natural sites of interest to the earth sciences: The regions of Crans-Montana-Sierre (Valais, Swiss Alps) and Chamonix-Mont-Blanc (Haute-Savoie, French Alps). Doctorat thesis presented at the Faculty of Geosciences and Environment of the University of Lausanne. https://dx.doi.org/10.1108/eb058476

Predrag, D., \& Mirela, D. (2010). Inventory of Geoheritage Sites - the Base of Geotourism Development in Montenegro. Geographica Pannonica, 14(4). 126132. https://doi.org/10.5937/GeoPan1004126D

Ranjbaran, M., Zamanzadeh, S.M., \& Sotohian, F. (2020). Geotourism Attractions of Hormuz Island, Iran. GeoJournal of Tourism and Geosites, 28(1), 232245. https://doi.org/10.30892/gtg.28118-465

Reynard, E., Pica, A., \& Coratza P. (2017). Urban geomorphological heritage. An overview. Quaestiones Geographicae, Bogucki Wydawnictwo Naukowe, Poznań, 36(3), 7-20. https://doi.org/10.1515/quageo-2017-0022

Reynard, E., \& Brilha, J. (2018). Geoheritage: assessment, protection and management, Elsevier, Amsterdam,1-450

Robles, M.P., Guerrera, F., Martín, M.M.G., Raffaelli, F.J., Alcalá, J., Tejera de León, T.E., Cherkaoui, L., Asebriy, I.E., El Amraniand, S., \& Moliner, A. (2015). Geological risk assessment of Amtoudi Agadir in southern Morocco: a key case for sustainable cultural heritage. Nat Hazards, 75, 415-440. https://doi.org/10.1007/s11069-014-1329-7

Weisrock, A., Wengler, L., Mathieu, J., Ouammou, A., Fontugne, M., Mercier, N., Reyss, J.L., Valladas, H., \& Guery, P. (2006). Upper Pleistocene comparativeOSL, U/Th and 14C datings of sedimentary sequences and correlative morphodynamical implications in the South-Western Anti-Atlas (Oued Noun, $29^{\circ} \mathrm{N}$, Morocco). Quaternaire, 17/1. https://doi.org/10.4000/quaternaire.645

*** High Commission for Planning (HCP) (2015). General population and housing census 2015. Available via the following link: http://www.hcp.ma/Recensementgeneral-de-la-population-et-de-1-habitat-2015_a633.html

*** High Commissioner for Water and Forests and the Fight against Desertification (HCWFFAD) (2008). Monographic Overview of the Forestry Sector in the Province of Guelmim.

*** Minister Of Energy, Mines, Water and the Environment (MEMWE). (2010). Second National Communication to the United Nations Framework Convention on Climate Change.

*** Souss Massa and Draa Hydraulic Basin Agency (SMDHBA). (2013). Water resources monograph in the province of Guelmim.

*** Souss Massa and Draa Hydraulic Basin Agency (SMDHBA). (2011). Study for the release of water resources and implementation of water catchments for the AEP of the centre of Guelmim. 